\title{
Model Analisis Kesenjangan di Bidang Manajemen Sumberdaya Manusia
}

\author{
Dwi Agus Kuncoro \\ Alumni MM UII Yogyakarta \\ aguskuncoro@yahoo.com
}

So far the Gap Analysis have been recognized in the areas of operational and marketing managements, and in fact these are different one and each other, based on their own characteristics. In the area of human resource management there has not been a standardized gap analysis, and therefore, it is necessary to develop one. This article will introduce a gap analysis for human resource management, and will show organization situation as a case study.

Keywords: gap analysis, management, organization, human resources

\section{Pendahuluan}

$S_{b}$ elama ini analisis kesenjangan yang biasa kita kenal, terdapat di bidang manajemen operasional dan pemasaran. Sebenarnya analisis kesenjangan untuk masing-masing bidang akan lain karakteristiknya. Seperti di bidang pemasaran dimana kita kenal formula rumus $A b=S W_{i} 1 / 2 I_{i}-X_{i}^{1} / 2$; disini terlihat bahwa nilai $A b$ akan selalu positif. Aplikasinya di bidang pemasaran, sangat cocok, dimana kita akan melakukan usaha untuk mendekati suatu sasaran yang berkaitan dengan optimalisasi pencapaian laba usaha. Contoh kasus sebagai berikut : suatu perusahaan produk "permen" akan memasarkan produknya ke suatu daerah, setelah dilakukan survai ternyata permen yang telah diproduksi tidak sesuai rasanya dengan keinginan calon konsumen di daerah tersebut, katakanlah terlalu manis. Perbedaan terlalu manis dengan kurang manis di sini sama saja, karena akan menurunkan jumlah penjualan produk permen tersebut yang akibatnya akan menurunkan laba, sehingga formula model tersebut cocok untuk aplikasi di bidang manajemen pemasaran.

Di bidang manajemen sumberdaya manusia hal tersebut sangat tidak cocok. Seperti contoh kasus berikut ini. Suatu pimpinan perusahaan ingin menaikkan produktivitas kerja karyawannya. Setelah dilakukan penelitian ternyata kebanyakan karyawan merasa gaji yang diterima terlalu sedikit karena kondisi krisis ekonomi yang berkepanjangan. Setelah dilakukan analisis, ternyata salah satu usaha untuk dapat menaikkan produktivitas kerja karyawannya adalah dengan menaikkan gaji karyawan. Tetapi disini dengan menaikkan gaji karyawan belum jaminan untuk dapat menaikkan produktivitas kerja mereka karena keinginan untuk bekerja keras tergantung dari sifat prilaku masing-masing karyawan tersebut. Dapat terjadi setelah dinaikkan gajinya ada karyawan yang produktivitas kerjanya meningkat ada juga yang produktivitas kerja yang tetap, bahkan ada yang produktivitas kerjanya menurun. Jadi disini diperlukan model analisis kesenjangan yang berbeda dengan formula kesenjangan di bidang manajemen pemasaran. 
Model Analisis Kesenjangan di Bidang Manajemen...; Dwi Agus Kuncoro

Dengan demikian terlihat, bahwa adanya perbedaan model analisis kesenjangan untuk masing-masing bidang terutama antara manajemen pemasaran dengan manajemen sumberdaya manusia. Perlu adanya model analisis kesenjangan yang lebih spesifik untuk manajemen sumberdaya manusia. Dengan mempertimbangkan hal tersebut di atas,
Setelah dapat dihitung sikap karyawan terhadap faktor i, maka dilakukan interpretasi skor dari nilai terendah hingga nilai tertinggi, selanjutnya skala tersebut dibagi menjadi beberapa interval sesuai dengan keinginan penganalisis dengan memperhatikan tingkat persaingan dari produk lain; dimana masingmasing interval tersebut mengandung pengertian, misalnya:

\begin{tabular}{|r|rrr|r|}
\hline & Sedikit beda & $\boldsymbol{*}$ Beda & Beda sekali & Sangat beda sekali \\
\hline 0 & $100 \mathrm{Ab}=150$ & 200 & 300 & 400
\end{tabular}

maka penulis mencoba menulis tulisan ini untuk dapat membuka wawasan kita mengenai model kesenjangan sebagai alat analisis yang dapat membantu kita untuk menentukan kebijakan yang akan di tempuh.

\section{Kajian Pustaka}

Dari formula rumus:

$A_{b}=$ å $W_{i}\left|I_{i}-X_{i b}\right|$, dimana

$A_{b}=$ sikap karyawan / pegawai terhadap iklim yang terbentuk.

$\mathrm{W}_{\mathrm{i}}=$ arti (importance) sifatfaktori bagi karyawan

$\mathrm{I}_{\mathrm{i}}=$ nilai kecenderungan/harapan dari faktor $\mathrm{i}$

$\mathrm{X}_{\mathrm{ib}}=$ nilai kenyataan dari faktor $\mathrm{i}$

Asumsi dari model tersebut di atas bahwa item-item yang terjadi di bawah harapan (ideal) sama dengan item-item yang terjadi di atas harapan, yaitu samasama tidak memenuhi harapan dari karyawan. Penentuan arti penting dari sifat i (item-item pembentuk iklim organisasi) dilakukan secara obyektif berdasarkan respon dari responden. Rumus tersebut merupakan pengembangan dari rumus $A_{b}=$ å $W_{i} X_{i b}$.
Formula rumus tersebut lazim digunakan di bidang manajemen pemasaran dengan mengidentifikasi sikap terhadap: produk/merk, situasi dan orang/tempat.

Menurut Ahmad Firdaus dan Jann Hidayat Tjakraatmadja (1997), bahwa kesenjangan merupakan nilai rata-rata kecenderungan (harapan) dikurangi dengan nilai rata-rata kenyataan sehingga kesenjangan dapat bernilai positif dan dapat bernilai negatif.

Kalau dirumuskan dalam bentuk matematikanya sebagai berikut:

$A_{b}=a ̊\left(I\right.$ rerata $-X_{i b}$ rerata $)$, dimana:

$A_{b}=$ sikap karyawan / pegawai terhadap iklim yang terbentuk.

$\mathrm{W}_{\mathrm{i}}=$ arti (importance) sifat/faktor $\mathrm{i}$ bagi karyawan

$\mathrm{I}_{\mathrm{i}}=$ nilai kecenderungan/harapan dari faktor $\mathrm{i}$ $\mathrm{X}_{\mathrm{ib}}=$ nilai kenyataan dari faktor $\mathrm{i}$

Setelah dapat diketahui nilai kesenjangan dari masing-masing faktor yang dianalisis, lalu diranking dari nilai terbesar hingga terkecil, maka nilai yang terbesar tersebutlah yang menjadi prioritas utama dalam melakukan aksi/tindakan. 
UNISIA, Vol. XXXI No. 69 September 2008

\section{Metode Penelitian}

Dari kajian pustaka tersebut di atas maka dapat secara ringkas model analisis kesenjangan untuk bidang manajemen sumberdaya manusia dapat diringkas sebagai berikut: ada pada model-model tersebut di atas pada kajian pustaka. Model ini dapat diformulasikan sebagai berikut:

Kesenjangan merupakan nilai rata-rata kenyataan dimensi "manajemen sumberdaya manusia" (contohnya iklim

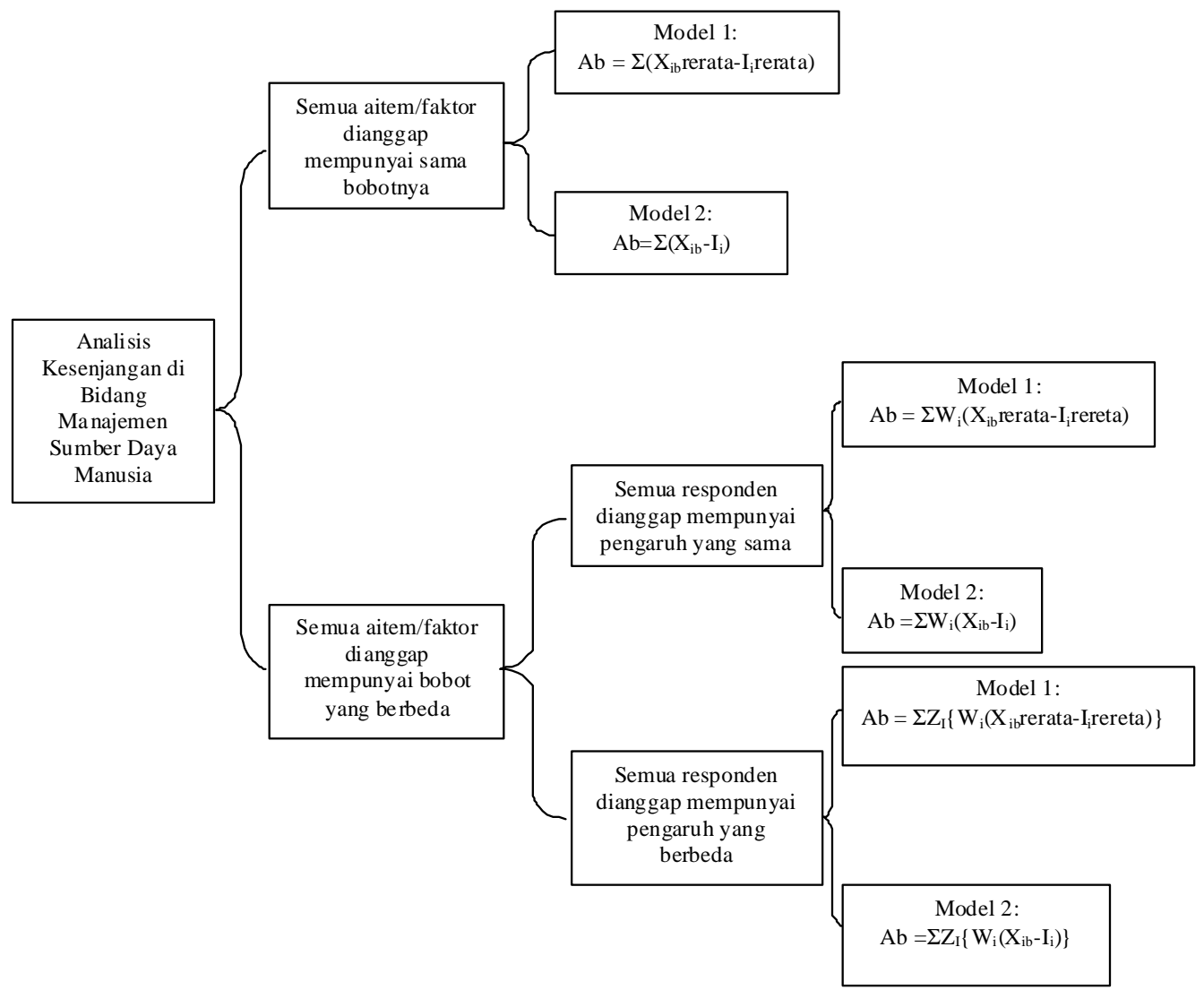

Gambar 1. Diagram yang menunjukkan berbagai model analisis kesenjangan di bidang manajemen sumber daya manusia.

Dari diagram tersebut di atas, maka dapat dibagi menjadi dua model analisis kesenjangan sebagai berikut:

\section{a. Model 1:}

Model ini disusun oleh peneliti sendiri dengan melihat beberapa kekurangan yang organisasi) yang terbentuk dikurangi dengan nilai rata-rata kecenderungan (harapan) dimensi iklim organisasi yang selanjutnya dipertimbangkan dengan bobot/arti penting dari dimensi iklim organisasi tersebut. Penentuan arti penting dari dimensi iklim organisasi ke-i dilakukan dengan analisis 
Model Analisis Kesenjangan di Bidang Manajemen...; Dwi Agus Kuncoro

dari data kuisioner (secara obyektif berdasarkan respon dari responden). Dengan demikian, kesenjangan dapat bernilai positif dan dapat bernilai negatif, apabila dibuat formula rumusnya yaitu:

$$
\begin{aligned}
& A_{b}=a ̊ W_{i}\left(X_{i b} \text { rerata }-I_{i b} \text { rerata }\right) \text {, dimana: } \\
& A_{b} I_{i b} \text { rerata } X_{i b} \text { rerataW } W_{1}=\text { nilai }
\end{aligned}
$$
kesenjangan yang terjadi dari item pertanyaan ke-i atau dimensi iklim organisasi $k e-i=$ nilai rata-rata kecenderungan / harapan dari item pertanyaan ke-i atau dimensi iklim organisasi $k e-i=$ nilai rata-rata kenyataan dari aitem pertanyaan ke-i atau dimensi iklim organisasi $\mathrm{ke}-\mathrm{i}=$ arti (importance) item pertanyaan ke-i atau dimensi iklim organisasi ke-i bagi karyawan

Setelah dapat diketahui nilai kesenjangan dari masing-masing aitem pertanyaan yang dianalisis, lalu diranking dari nilai terkecil hingga terbesar dari nilai kesenjangan tersebut, maka nilai rangking yang terbesar atau nilai kesenjangan yang terkecil (negatif) tersebutlah yang menjadi prioritas utama dalam melakukan aksi/ tindakan. Di sini terdapat perbedaan dengan analisis kesenjangan pada kajian pustaka (Ahmad Firdaus dan Hidayat Tjakraatmadja,1997), dimana kesenjangan positif (gaps $(+)$ ) ditunjukkan dengan nilai kesenjangan bernilai positif (+) sedangkan kesenjangan negatif (gaps (-)) ditunjukkan dengan nilai kesenjangan bernilai negatif ( ), sedangkan pada analisis kesenjangan pada kajian pustaka (Ahmad Firdaus dan Hidayat Tjakraatmadja,1997) sebaliknya. Perbedaan ini dimaksudkan bahwa untuk lebih memperhatikan agar sesuai dengan kaidah-kaidah matematis. Di samping itu perbedaannya juga terletak pada perhitungannya, dimana analisis kesenjangan pada kajian pustaka tersebut berasumsi, bahwa setiap faktor/dimensi/item pertanyaan mempunyai bobot pengaruh yang sama sedangkan pada model 1 ini berasumsi, bahwa setiap faktor/dimensi/ aitem pertanyaan mempunyai bobot pengaruh yang berbeda. Perbedaan bobot pengaruh ini di setiap tempat akan berlainan, tergantung pada kepuasan kerja dari karyawan. Di suatu tempat mungkin kepuasan kerja karyawan lebih mementingkan bila pimpinan memberikan perhatian lebih daripada pemberian fasilitas kerja atau lainnya, ini berarti bobot pengaruh dari dimensi socio-emotional support akan lebih besar pengaruhnya daripada dimensidimensi yang lainnya, begitu sebaliknya.

\section{b. Model 2:}

Model ini disusun oleh peneliti sendiri dengan melihat beberapa kekurangan yang ada pada model-model tersebut di atas pada kajian pustaka. Model ini dapat diformulasikan sebagai berikut:

Dalam situasi seperti ini, kita perlu menentukan suatu " titik ideal " atau " titik harapan " ke dalam model sikap atribut ganda:

$A_{b}=$ å $W_{i}\left(X_{i b}-I_{i b}\right)$, dimana:

$A_{b}=$ sikap karyawan/pegawai terhadap iklim yang terbentuk atau nilai kesenjangan yang terjadi.

$\mathrm{W}_{\mathrm{i}}=$ arti (importance) aitem pertanyaan kei atau dimensi iklim organisasi ke-i bagi karyawan

$\mathrm{I}_{\mathrm{ib}}=$ nilai kecenderungan/harapan dari aitem pertanyaan ke-i atau dimensi iklim organisasi ke-i

$\mathrm{X}_{\mathrm{ib}}=$ nilai kenyataan dari aitem pertanyaan ke-i atau dimensi iklim organisasi ke-i

Asumsi dari model tersebut di atas bahwa item-item yang terjadi dibawah harapan (ideal) tidak sama dengan item-item yang terjadi di atas harapan. Penentuan arti penting dari dimensi iklim organisasi ke-i 
UNISIA, Vol. XXXI No. 69 September 2008

dilakukan dengan analisis dari data kuisioner (secara obyektif berdasarkan respon dari responden).

Setelah dapat dihitung sikap karyawan terhadap aitem pertanyaan atau dimensi iklim organisasi ke-I, maka dilakukan interpretasi skor dari nilai terendah hingga nilai tertinggi, selanjutnya skala tersebut dibagi menjadi beberapa interval dengan menggunakan kategorisasi berdasar model distribusi normal dan berdasar signifikansi perbedaan, dimana masing-masing interval tersebut mengandung pengertian, misalnya:

Jadi iklim organisasi yang terbentuk (kenyataan) mempunyai kesenjangan dengan kriteria "sedikit beda di atas harapan" dengan iklim organisasi yang diharapkan (kecenderungan).

\section{Pembahasan}

Dari dua model analisis kesenjangan tersebut dapat diidentifikasi bahwa kedua model mempunyai kelemahan dan kelebihan sebagai berikut:

\section{a. Model 1}

Model ini mempunyai kelebihan yaitu secara cepat dapat dihitung analisis kesenjangannya dibandingkan dengan model 2; apabila jumlah responden yang kita teliti berjumlah sangat banyak. Tetapi model ini mempunyai kelemahan yaitu apabila distribusi jawaban dari responden antar ekstrim pilihan jawaban sangat besar, misalnya: jumlah responden 100 orang, dari 100 orang tersebut yang memilih jawaban: A sebanyak 30 orang, B sebanyak 10 or- ang, C sebanyak 20, D sebanyak 10 orang dan E sebanyak 30 orang. Jadi model 1 ini akan lebih baik dipakai bila distribusi jawabannya mempunyai simpangan yang kecil. Bila dilihat dari distribusi jawaban tersebut, maka akan terkait dengan validitas dari item pertanyaan dari kuisioner. Item pertanyaan yang dipakai dalam penelitian yaitu item pertanyaan yang valid; dan item pertanyaan yang valid akan mempunyai distribusi jawaban yang mengumpul/ mengarah kesalah satu pilihan jawaban.

Dengan demikian, dapat dikatakan bahwa untuk model 1 akan cocok diterapkan bila respondennya sangat banyak dan aitemaitem pertanyaan pada kuisioner yang dipakai mempunyai validitas yang sangat tinggi $(r=0,8-1)$.

\section{b. Model 2}

Model ini mempunyai kelebihan yaitu dapat diterapkan untuk segala situasi (misalnya untuk jumlah responden yang sedikit atau banyak, item pertanyaan yang mempunyai validitas yang rendah tetapi masih dalam kategori valid dsb). Tetapi model ini mempunyai kelemahan yaitu lebih lambat dihitung analisis kesenjangannya dibandingkan dengan model 1: apabila jumlah responden yang kita teliti berjumlah sangat banyak.

Hasil analisis kesenjangan yang didapatkan dari model 1 dan model 2 tidak signifikan berbeda; apabila jumlah respondennya sangat banyak dan validitas item pertanyaan pada kuisioner yang dipakai 
Model Analisis Kesenjangan di Bidang Manajemen...; Dwi Agus Kuncoro

dalam penelitian sangat tinggi $(r=0,8-1)$. Pada diagram 1 tersebut di muka terlihat, bahwa terdapat beberapa model analisis kesenjangan dimana dari yang sederhana sampai yang kompleks. Apabila data yang akan dianalisis tersedia secara lengkap, maka sebaiknya menggunakan model analisis yang kompleks, seperti: model $\mathrm{Ab}$ $=S Z_{1}\left\{W_{i}\left(X_{i b}-I_{i}\right)\right\}$ atau model $A b=S W_{i}\left(X_{i b}-I_{i}\right)$, dimana:

$A_{b}=$ sikap karyawan / pegawai terhadap iklim yang terbentuk atau nilai kesenjangan yang terjadi.

$Z_{i}=$ pengaruh dari karyawan yang menjadi responden tersebut dalam organisasi terhadap suatu permasalahan yang sedang diteliti seperti pembentukan iklim organisasi. $\mathrm{W}_{\mathrm{i}}=$ arti (importance) aitem pertanyaan kei atau dimensi iklim organisasi ke-i bagi karyawan

$\mathrm{I}_{\mathrm{ib}}=$ nilai kecenderungan/harapan dari aitem pertanyaan ke-i atau dimensi iklim organisasi ke-i

$\mathrm{X}_{\mathrm{ib}}=$ nilai kenyataan dari aitem pertanyaan ke-i atau dimensi iklim organisasi ke-i

\section{Penutup}

Dari uraian pada pembahasan tersebut di atas, maka dapat disimpulkan sebagai berikut:

1. Untuk jumlah responden yang sedikit maka sebaiknya menggunakan model 2 .
2. Untuk jumlah responden yang berjumlah sangat banyak, validitas aitem pertanyaan pada kuisioner sangat tinggi $(r=0,8-1)$ serta mempunyai simpangan dari distribusi jawaban yang kecil, maka sebaiknya menggunakan model 1 atau model 2.

3. Bila dibandingkan antara model 1 dan model 2, maka dapat dikatakan bahwa model 2 ini lebih baik atau lebih fleksibel dipakai untuk kondisi apapun.

\section{Daftar Pustaka}

Firdaus, A., dan Tjakraatmadja, J., H., Perilaku Individu Sebagai Dasar Rekayasa Organisasi, 1997.Makalah Seminar Nasional Forum Komunikasi Penelitian Manajemen dan Bisnis, Surabaya:MM Universitas Airlangga.

Kuncoro, D., A.,2000. Peranan Iklim Organisasi Dalam Meningkatkan Produktivitas Kerja Pegawai di Cabang Dinas Pekerjaan Umum Pengairan Bengawan Solo Klaten, Yogyakarta:Tesis MM UII.

Loundon, D., dan Bitta, A. 1988, Consumer Behavior, Concepts And Aplication, Singapore:Mc Graw Hill, Edisi Ketiga. 